\title{
Pengaruh Profitabilitas, Likuiditas, Ukuran Perusahaan, Dan Struktur Aset Terhadap Struktur Modal
}

\author{
Dini Novita Sari \\ Program Studi Akuntansi, Fakultas Ekonomika dan Bisnis, Universitas Muhammadiyah Prof. DR. \\ HAMKA, Jakarta, Indonesia
}

\section{Corresponding Author}

Nama Penulis : Dini Novita Sari

E-mail : dinins28@gmail.com

\begin{abstract}
Abstrak
Tujuan dari penelitian ini adalah untuk mengetahui pengaruh profitabilitas, likuiditas, ukuran perusahaan, dan struktur aset terhadap struktur modal. Populasi dalam penelitian ini adalah perusahaan Sub sektor perkebunan yang terdaftar di Bursa Efek Indonesia (BEI), Adapun teknik pengambilan sampel yang digunakan adalah purposive sampling dengan sampel yang terpilih sebanyak 5 (lima) perusahaan. Teknik pengolahan dan analisis data yang digunakan adalah analisis akuntansi, analisis statistik deskriptif, analisis regresi linear berganda, uji asumsi klasik, koefisien determinan, dan uji hipotesis dengan menggunakan SPSS versi 22. Hasil pengujian menunjukkan bahwa profitabilitas dan likuiditas berpengaruh secara parsial terhadap struktur modal dengan nilai signifikan kurang dari 0,05. Sedangkan ukuran perusahaan dan struktur aset tidak berpengaruh secara parsial terhadap struktur modal karena memiliki nilai signifikan lebih besar daru 0,05. Adapun secara simultan menunjukkan profitabilitas, likuiditas, ukuran perusahaan, dan struktur aset berpengaruh signifikan terhadap struktur modal dengan nilai signifikan sebesar $0,00<0,05$.
\end{abstract}

Kata kunci : Profitabilitas, Likuitas, Ukuran Perusahaan, Struktur Aset, Struktur Modal

\begin{abstract}
The purpose of this study are to determine the effect of profitability, liquidity, firm size, and assetsstructure on capital structure. The research population is a plantation sub sector listed in IDX. While the sampling techniques used is purposive sampling with a selected sample 5 (five) companies. Data processing and analysis technique used are accounting analysis, descriptive statistical analysis, multiple linier regression analysis, coefficient of determination hypothesis test by using SPSS version 22. The test result show that profitability and liquidity have a partial significant effect on capital structure with a significant value under 0,05 . While firm size and assets structure have a not a partial significant effect on capital structure with a significant up to 0,05. Simultaneously show that profitability, liquidity, firm size, and assets structure have a significant effect on capital structure with a significant value $0,00<0,05$.
\end{abstract}

Keywords : Profitability, Likuidity, Firm Size, Assets Structure, and Capital Structure 


\section{PENDAHULUAN}

Dalam perkembangan globalisasi yang semakin modern seperti ini sangat menuntut perusahaan untuk memanfaatkan kemampuan yang ada semaksimal mungkin, agar unggul dalam persaingan bisnis. Perusahaan mengupayakan berbagai cara untuk menjadi lebih baik sehingga dapat bersaing dengan perusahaan lain. Salah satu upaya yang dilakukan oleh perusahaan adalah kaitanya dengan operasional perusahaan yaitu penentuan keputusan struktur modal yang dihadapi oleh manajer keuangan.

Visi dan misi setiap perusahaan berbeda-beda. Tetapi secara umum, perusahaan tidak hanya dituntut untuk mendapatkan laba maksimal, tetapi juga diharapkan mampu mensejahterakan pemegang saham dan meningkatkan nilai perusahaan. Untuk mencapai tujuannya tersebut, perusahaan memerlukan pendanaan yang cukup dengan kebutuhan dana yang mencukupi pula guna mampu menghasilkan produk-produk yang berkualitas tinggi dan mampu bersaing dipasaran (Bhawa dan Made, 2015).

Dalam hal ini perusahaan harus mengetahui terlebih dahulu biaya yang dibutuhkan untuk memperoleh dana tersebut (cost of capital). Demikian dalam mempertimbangkan kebijkan struktur modal tersebut ada satu permasalahan yang sering timbul, yakni seberapa besar total hutang perusahaan dan seberapa besar total aset yang telah didapat perusahaan dan seberapa besar total yang harus digunakan oleh perusahaan (Budiyanto dan Agustini, 2015).

Struktur modal merupakan gambaran dari proporsi finansial perusahaan yaitu antara modal yang dimiliki yang bersumber dari hutang jangka panjang dan modal sendiri yang menjadi sumber pembiayaan suatu perusahaan. Kebutuhan dana untuk memperkuat struktur modal suatu perusahaan dapat bersumber dari ketentuan sumber dana yang dibutuhkan tersebut yang bersumber dari tempat- tempat yang dianggap aman dan jika dipergunakan memiliki nilai dorong dalam memperkuat struktur modal keuangan perusahaan.

Profitabilitas menunjukkan kemampuan perusahaan dalam memperoleh laba. Perusahaan yang mempunyai profitabilitas yang tinggi cenderung mempunyai tingkat hutang yang rendah. Profitabilitas dapat mempengaruhi struktur modal dari besar kecilnya laba yang dihasilkan oleh perusahaan..

Likuiditas merupakan kemampuan perusahaan dalam melunasi hutang jangka pendeknya. Apabila perusahaan memiliki tingkat likuiditas tinggi maka perusahaan tidak akan menggunakan pembiayaan dari hutang. Ukuran perusahaan merupakan suatu ukuran dari besar kecilnya suaru perusahaan. Perusahaan-perusahaan besar cenderung memiliki sumber permodalan yang lebih tertata dan nilai aset yang cukup besar maka perusahaan akan lebih mudah memperoleh pinjaman.

Struktur aset menggambarkan jika perusahaan mempunyai banyak aset cenderung merasa cukup dalam memenuhi kebutuhan utangnya. Struktur aset juga digunakan untuk menompang jalanya operasional bisnis, jika struktur aset tetap banyak maka perusahaan akan memaksimalkan hal tersebut dengan utang sebagai pemenuhan kebutuhan modalnya. 
Dini Novita Sari, Pengaruh Profitabilitas, Likuiditas, Ukuran Perusahaan, Dan Struktur Aset Terhadap Struktur Modal Struktur aset besar tetap yang besar bisa dijadikan sebagai jaminan atas pinjamanpinjaman yang dilakukan.

\section{TINJAUAN PUSTAKA DAN PERUMUSAN HIPOTESIS}

\section{Struktur Modal}

Menurut (Wiagustini, 2014 : 88) struktur modal adalah keputusan pendanaan yang dilakukan oleh manajer keuangan yang berkaitan dengan bagaimana membiayai keputusan investasi yang akan dilakukan perusahaan. Sementara itu, (Mustafa, 2017 : 85) menyatakan bahwa struktur modal adalah perimbangan atara jumlah utang jangka pendek yang besifat permanen, utang jangka panjang, saham preferen dan saham biasa. Struktur modal adalah perbandingan modal asing atau jumlah utang dengan modal sendiri. Kebijaksanaan struktur modal merupakan pemeliharaan antara risiko dan pengambilan yang diharapkan. Berbeda dengan (Fahmi, 2015 :184), yang menyatakan bahwa struktur modal adalah gambaran dari bentuk proporsi finansial perusahaan yaitu antara modal yang dimiliki yang bersumber dari utang jangka panjang (long-tern liability) dan modal sendiri (share holders equity) yang menjadi sumber pembiayaan suatu perusahaan. Penelitian ini menggunakan proksi Debt Equity Ratio (DER).

\section{Profitabilitas}

Menurut (Murhadi, 2013 : 63) profitabilitas adalah rasio ini menggambarkan kemampuan perusahaan untuk menghasilkan keuntungan. rasio laba umumnya diambil dari laporan keuangan laba rugi. Menurut (Hanafi, 2016 : 63) profitabilitas adalah rasio profitabilitas mengukur kemampuan perusahaan menghasilkan keuntungan (profitabiltas) pada tingkat penjualan, aset, dan modal saham tertentu. Lalu Menurut (Munawir, 2014 : 86) profitabilitas adalah rasio untuk mengukur profit yang diperoleh dari modal-modal yang digunakan untuk operasi tersebut atau mengukur kemampuan perusahaan untuk memperoleh keuntungan. Sementara itu, (Hery, 2016:152) menyatakan bahwa profitabilitas rasio yang digunakan untuk mengukur kemampuan perusahaan dalam menghasilkan laba dari aktivitas normal bisnisnya. Rasio profitabilitas dapat diukur dengan membandingkan antara berbagai komponen yang ada di dalam laba rugi dan atau neraca. Pengukuran yang digunakan adalah Return on Asset (ROA).

\section{Likuiditas}

Menurut (Fahmi, 2015 :121) likuiditas adalah Seberapa besar kemampuan perusahaan dalam memenuhi kewajiban jangka pendeknya pada saat jatuh tempo. Menurut (Hery, 2016 :149) likuiditas adalah rasio yang menunjukan kemampuan perusahaan dalam memenuhi kewjiban atau menunjukan kemampuan perusahaan dalam memenuhi kewajiban atau membayarutang jangka pendeknya. Sedangkan menurut(Kasmir, 2016 :129) menyatakan bahwa likuiditas adalah rasio yang menggambarkan kemampuan perusahaan dalam memenuhi kewajiban (utang) jangka pendek. Artinya apabila perusahaan ditagih, perusahaan akan mampu untuk memenuhi utang tersebut terutama utang yang sudah jatuh tempo. Pengukuran yang digunakan adalah Current Ratio (CR). 
Dini Novita Sari, Pengaruh Profitabilitas, Likuiditas, Ukuran Perusahaan, Dan Struktur Aset Terhadap Struktur Modal

\section{Ukuran Perusahaan}

Menurut (Jogiyanto, 2016:685) ukuran perusahaan adalah besar kecilnya perusahaan yang dapat diukur dengan nilai total aktiva atau penjualan bersih atau nilai ekuitas. Sementara itu, (Bambang, 2013:313) menyatakan bahwa ukuran perusahaan adalah besar kecilnya perusahaan yang dapat dilihat dari besarnya nilai aktiva, nilai penjualan, atau nilai ekuitas. Sedangkan menurut (Hartono, 2015 : 254) menyatakan bahwa ukuran perusahaan merupakan besar kecilnya perusahaan dapat diukur dengan total aktiva atau besar harta perusahaan dengan menggunakan perhitungan nilai logaritma total aktiva.

\section{Struktur Aset}

Menurut (Sitanggang, 2013 : 75) struktur aset merupakan Perusahaan yang memiliki aset tetap yang banyak dan bernilai tinggi, perusahaan dapat memanfaatkan asset tersebut untuk mendapatkan modal tambahan dari luar perusahaan atau external financing yaitu melalui hutang. Sedangkan menurut (Mulyawan, 2015 : 224) struktur aset adalah Susunan aset kebanyakkan industri atau manufaktur yang sebagian besar modalnya tertanam dalam aktiva tetap cenderung menggunakan modal sendiri dibandingkan dengan modal asing atau utang hanya sebagai pelengkap. Pengukuran yang digunakan adalah Fixed Asset Ratio (FAR).

\section{Hipotesis}

Berdasarkan kerangka penelitian teoritis yang telah penulis uraikan di atas maka penulis akan mengemukakan hipotesis sebagai dugaan sementara dari penelitian ini dan selanjutnya dapat diuji kebenarannya sebagai berikut:

H1 : Secara parsial Profitabilitas berpengaruh terhadap Struktur Modal. H2 : Secara parsial

Likuiditas berpengaruh terhadap Struktur Modal.

H3 : Secara parsial Ukuran Perusahaan berpengaruh terhadap Struktur Modal. H4 : Secara parsial Struktur Aset berpengaruh terhadap Struktur Modal.

H5 : Secara Simultan Profitabilitas, Likuiditas, Ukuran Perusahaan, dan Struktur Aset berpengaruh terhadap Struktur Modal.

\section{METODE}

Penelitian ini menggunakan motode pendekatan eksplanasi. (Sugiyono, 2013 : 6), menjelaskan bahwa penelitian eksplanasi (exsplanatory research) adalah penelitian yang menjelaskan kedudukan antara variabel-variabel diteliti serta hubungan antara variabel yang satu dengan yang lain melalui pengujian hipotesis yang telah dirumuskan. Pada penelitian ini populasinya adalah perusahaan sub sektor perkebunan yang terdaftar di Bursa Efek Indonesia tahun 2013-2019. Jumlah populasi dalam penelitian ini sebanyak 16 perusahaan.

\section{ANALISIS DATA}

Analisis akuntansi dilakukan untuk melihat nilai masing-masing variabel independen dan variable dependen dengan melihat hasil dari perhitungan yang telah dioleh secara deskriptif. Disamping itu dilakukan nilai maksimum, nilai minimum, mean dan standar deviasi. 
Dini Novita Sari, Pengaruh Profitabilitas, Likuiditas, Ukuran Perusahaan, Dan Struktur Aset Terhadap

Struktur Modal

Analisis Statistik Deskriptif. Menurut (Sugiyono, 2016 : 35), metode deskriptif adalah suatu rumusan masalah yang berkenaan dengan pertanyaan terhadap keberadaan variabel mandiri, baik hanya pada satu variabel atau lebih (variabel yang berdiri sendiri). Analisis deskriptif digunakan untuk menggambarkan dan mendeskripsikan variabel-variabel yang digunakan dalam penelitian ini.

Analisis Regresi Liniear Berganda

Analisis regresi adalah sebuah pendekatan yang digunakan untuk mendefinisikan hubungan matematis antara variabel output/dependen $(Y)$ dengan satu atau beberapa variabel input/independen (X) (Yamin dan Kurniawan, 2014 : 82). Dalam penelitian ini, analisis regresi digunakan untuk mengetahui seberapa kuat pengaruh profitabilitas, likuiditas, ukuran perusahaan dan struktur aktiva terhadap struktur modal.

Bentuk persamaannya adalah: $\mathrm{Y}=\alpha+\mathrm{b} 1 \mathrm{X} 1+\mathrm{b} 2 \mathrm{X} 2+\mathrm{b} 3 \mathrm{X} 3+\mathrm{e}$.

Keterangan:

$\begin{array}{ll}\mathrm{Y} & =\text { Struktur modal } \\ \alpha & =\text { Konstanta } \\ \mathrm{b} 1-\mathrm{b} 4 & =\text { Koefisien regresi } \\ \mathrm{X} 1 & =\text { Profitabilitas } \\ \mathrm{X} 2 & =\text { Likuiditas } \\ \mathrm{X} 3 & =\text { Ukura perusahaan } \\ \mathrm{X} 4 & =\text { Struktur aset } \\ \mathrm{e} & =\text { Kesalahan residual }\end{array}$

\section{Uji Asumsi Klasik}

Uji Normalitas

Uji normalitas bertujuan untuk menguji apakah dalam model regresi, variable dependen dan independen keduanya mempunyai distribusi normal atau tidak. Model regresi yang baik adalah memiliki distribusi normal atau mendekati normal.

Uji Multikolonieritas

Uji multikolinieritas bertujuan untuk menguji apakah dalam model regresi ditemukan adanya korelasi antar variabel independen. Model regresi yang baik seharusnya tidak terjadi korelasi di antara variabel-variabel independen.

Uji Autokorelasi

Uji autokorelasi digunakan untuk mengetahui apakah dalam sebuah model regresi linier ada korelasi antar kesalahan peganggu pada periode $t$ dengan kesalahan pada periode $t$ 1 (sebelumnya). Model regresi yang baik adalah regresi yang bebas dari autokorelasi (Santoso, 2014 :192).

\section{Uji Heteroskedastisitas}

Uji heteroskedastisitas digunakan untuk mengatasi apakah dalam sebuah model regresi, terjadi ketidaksamaan varians residual dari satu pengamatan ke pengamatan lain. Jika varians dari residual satu pengamatan ke pengamatan lain tetap, maka disebut 
Dini Novita Sari, Pengaruh Profitabilitas, Likuiditas, Ukuran Perusahaan, Dan Struktur Aset Terhadap Struktur Modal homoskedastisitas dan jika berbeda disebut heteroskedastisitas. Model regresi yang baik adalah yang homoskedastisitas atau tidak terjadi heteroskedastisitas (Santoso, 2014 :187).

\section{Pengujian Hipotesis}

\section{Uji t (Uji signifikasi parsial)}

Uji statistik t pada dasarnya menunjukan seberapa jauh pengaruh satu variabel penjelas/independen secara individual dalam menerangkan variasi variabel dependen. Uji statistik $t$ dilakukan untuk menunjukan seberapa jauh pengaruh profitabilitas, likuiditas, ukuran perusahaan secara individual dalam menerangkan variasi struktur modal.

\section{Uji Simultan (F)}

Uji statistic F menunjukkan apakah semua variabel independent atau variabel bebas dimasukan daam model mempunyai pegaruh secara bersama-sama terhadap variable dependen atau terikat. Uji statistik $\mathrm{F}$ juga digunakan untuk mengetahui pengaruh semua variabel independent yang dimasukan dalam model regresi secara bersama-sama terhadap variabel dependen yang diuji pada tingkat signifikan 0,05. Uji Koefisien Determinasi (R2)

Koefisien determinasi (R2) digunakan untuk mengetahui persentase pengaruh variabel independent terhadap perubahan variabel dependen. Dari sini kita akan ketahui seberapa besar variabel dependen mampu dijelaskan oleh variabel independennya, sedangkan sisanya dijelaskan oleh sebab sebab lain di luar model. Nilai yang mendekarti satu variabel-varibel independent memberikan hampir semua informasi yang dibutuhkan oleh mempredisi variasi variabel dependen.

\section{HASIL PENELITIAN DAN PEMBAHASAN}

\section{Pengaruh Profitabilitas Terhadap Struktur Modal}

Berdasarkan hasil pengujian hipotesis dapat diketahui bahwa variabel profitabilitas berpengaruh terhadap struktur modal. Hal ini dapat dilihat dari nilai signifikansi sebesar 0,014 lebih kecil dari 0,05 (0,014<0,05) dengan nilai thitung sebesar -2,624 dengan demikian maka hipotesis $\mathrm{H} 1$ diterima. Hal tersebut menunjukkan bahwa profitabilitas secara parsial berpengaruh signifikan terhadap struktur aset artinya apabila profitabilitas mengalami kenaikan maka diikuti denganpeningkatan struktur modal. Hasil dari penelitian ini didukung oleh penelitian sebelumnya yang telah dilakukan oleh (Muhammad, 2016) dan (Dewi, 2017) yang menyatakan bahwa profitabilitas berpengaruh signifikan terhadap struktur modal.

\section{Pengaruh Likuiditas Terhadap Struktur Modal}

Berdasarkan hasil pengujian hipotesis dapat diketahui bahwa variabel likuditas berpengaruh terhadap struktur modal. Hal ini dapat dilihat dari nilai signifikansi 0,001 lebih kecil dari 0,05 $(0,001<0,05)$ dengan niali thutang sebesar -

3,812 dengan demikian maka hipotesisi H2 diterima. Hal tersebut menunjukkan likuiditas berpengaruh signifikan terhadap struktur modal artinya apabila likuiditas mengalami peningkatkan maka diikuti dengan peningkatan struktur modal. Hasil penelitian ini sejalan 
Dini Novita Sari, Pengaruh Profitabilitas, Likuiditas, Ukuran Perusahaan, Dan Struktur Aset Terhadap

Struktur Modal

dengan hasil penelitian sebelumnya yang telah dilakukan oleh (Watung dkk, 2016) yang menyatakan bahwa likuidtas mempengaruhi struktur modal.

\section{Pengaruh Ukuran Perusahaan Terhadap Struktur Modal}

Berdasarkan hasil pengujian hipotesis dapat diketahui bahwa variabel ukuran perusahaan tidak berpengaruh terhadap struktur modal. Hal ini dapat dilihat dari nilai signifikan 0,215 lebih besar dari $0,05(0,215>0,05)$ dengan nilai thitung sebesar

1,267 dengan demikian maka hipotesis H3 ditolak. Hasil tersbut menunjukkan ukuran perusahaan secara parsial tidak berpengaruh signifikan terhadap struktur modal artinya apabila ukuran perusahaan mengalami peningkatan tidak diikuti dengan peningkatan struktur modal. Hasil penelitian ini sejalan dengan hasil penelitian sebelumnya yang telah dilakukan oleh (Bhawa dan Dewi, 2015), (Dewi,

2017) dan (Widyaningrum, 2015) yang menyatakan bahwa ukuran perusahaan tidak berpengaruh terhadap struktur modal.

\section{Pengaruh Struktur Aset Terhadap Struktur Modal}

Berdasarkan hasil pengujian hipotesis dapat diketahui bahwa variabel ukura perusahaan tidak berpengaruh terhadap struktur modal. Hal ini dapat dilihat dari_nilai signifikan 0,215 lebih besar dari 0,05 $(0,215>0,05)$ dengan nilai thitung sebesar_1,267 dengan demikian maka hipotesis H3 ditolak. Hasil tersbut menunjukkan ukuran perusahaan secara parsial tidak berpengaruh signifikan terhadap struktur modal artinya apabila ukuran perusahaan mengalami peningkatan tidak diikuti dengan peningkatan struktur modal. Hasil penelitian ini sejalan dengan hasil penelitian sebelumnya yang telah dilakukan oleh (Bhawa dan Dewi, 2015), (Dewi, 2017) dan (Widyaningrum, 2015) yang menyatakan bahwa ukuran perusahaan tidak berpengaruh terhadap struktur modal.

\section{Pengaruh Profitabilitas, Likuiditas, Ukuran perusahaan dan Struktur Aset Terhadap}

\section{Struktur Modal}

Berdasarkan hasil pengujian Signifikansi F dapat diperoleh secara empiris bahwa menunjukkan nilai sinifikansi lebih kecil dari 0,05 $(0,00<0,05)$. Dengan demikian dapat disimpulkan bahwa Ha diterima dan hipotesis H5 diterima, dimana variabel (independen) yaitu profitabilitas, likuditas, ukuran perusahaan dan struktur aset secara bersama-sama (simultan) berpengaruh signifikan terhadap struktur modal.

\section{KESIMPULAN}

Berdasarkan hasil dari pengujian analisis regresi linear berganda yaitu, konstanta sebesar 2,807 yang artinya jika profitabilitas (X1), likuiditas (X2), ukuran perusahaan (X3), struktur aset (X4) bernilai 0 (nol), maka struktur modal (Y) mengalami kenaikan sebesar 2,807. Hasil pengujian dari uji $t$ variabel profitabilitas menghasilkan nilai signifikan sebesar 0,014 < 0,05 yang artinya H1 diterima., yaitu secara parsial variabel profitabilitas memiliki pengaruh signifikan terhadap struktur modal pada sektor perkebunan yang terdaftar di Bursa Efek Indonesia. Hasil pengujian dari uji tlikuiditas menghasilkan nilai signifikan sebesar 0,001 < 0,05 yang artinya H2 diterima, yaitu secara parsial variabel likuiditas memiliki pengaruh signifikan terhadap struktur modal pada sektor perkebunan yang terdaftar di Bursa 
Dini Novita Sari, Pengaruh Profitabilitas, Likuiditas, Ukuran Perusahaan, Dan Struktur Aset Terhadap Struktur Modal

Efek Indonesia. Hasil pengujian dari uji $t$ variabel ukuran perusahaan menghasilkan nilai signifikan sebesar 0,215 > 0,05 yang artinya H3 ditolak, yaitu secara parsial variabel ukuran perusahaan tidak memiliki pengaruh signifikan terhadap struktur modal pada sektor perkebunan yang terdaftar di Bursa Efek Indonesia. Hasil pengujian dari uji t variabel struktur aset menghasilkan nilai signifikan sebesar 0,058>0,05 yang artinya H4 ditolak, yaitu secara parsial variabel struktur aset tidak memiliki pengaruh signifikan terhadap struktur modal pada sektor perkebunan yang terdaftar di Bursa Efek Indonesia. Berdasarkan hasil dari uji statistik F, diperoleh bahwa variabel profitabilitas, likuiditas, ukuran perusahaan, dan struktur aset secara bersama- sama berpengaruh terhadap struktur modal, hal ini dapat dilihat dari hasil signifikan sebesar $0,000<0,05$.

\section{Daftar Pustaka}

Bambang Riyanto. (2013). Dasar-Dasar Pembelajaran Perusahaan. Edisi Keempat. Yogyakarta: BPFE. Bhawa, I.B.M.D., dan Made Rusmala

Dewi S. (2015). Pengaruh Ukuran Perusahaan, Likuidutas,

Profitabilitas, dan Risiko Bisnis Terhadap Struktur Modal, Perusahaan Farmasi. Jurnal Manajemen: 4 (7), 1949-1966.

Budiyanto dan Agustini T. (2015). Pengaruh Struktur Aktiva, Profitabilitas, dan Ukuran Perusahaan Terhadap Struktur Modal. Jurnal Ilmu dan Riset Manajemen: Vol.4, No.4.

Dewi, Dewa Ayu Intan Yoga Maha, dan Sudiarta, Gede Mertha. (2017). Pengaruh Profitabilitas, Ukuran perusahaan, dan Pertumbuhan Aset Terhadap Struktur Modal dan Nilai Perusahaan. E-Jurnal Manajemen Unud. Vol. 6, No.4, 2222.2252.

Fahmi, Irham. (2015). Pengantar Manajemen Keuangan, Edisi Keempat.Bandung: Alfabeta.

Fahmi, Irham. (2015). Pengantar Manajemen Keuangan, Edisi Keempat. Bandung: Alfabeta.

Hanafi, Mamduh M. (2016). Manajemen Keuangan, Edisi Kedua. Yogyakarta: BPFE. Hartono, Jogiyanto. (2015). Teori Portofolio dan Analisis Investasi. Edisi Kelima. akarta: Rajawali Pers.

Hery. (2016). Analisa Laporan Keuangan. Jakarta: Grasindo.

Jogiyanto. (2016). Teori Portofolio dan Analisis Investasi. Edisi Kesepuluh. Yogyakarta: BPFE. Kasmir. (2016). Analisa Laporan Keuangan. Jakarta: Grasindo.

Muhardi, Werner R. (2013). Analisis Laporan Keuangan, Proyeksi dan Valuasi Saham. Jakarta: Salemba Empat. 
Dini Novita Sari, Pengaruh Profitabilitas, Likuiditas, Ukuran Perusahaan, Dan Struktur Aset Terhadap

Struktur Modal

Muhhammad Nur Fadilillah, dan Dewa Putra. (2016). Pengaruh Struktur Aktiva, Ukuran

Perusahaan dan Profitabilitas Terhadap Struktur Modal. E- Proceeding of

Management: Vol. 3, No.3.

Mulyawan, Setia. (2015). Manajemen Keuangan. Bandung: CV Pustaka Setia.

Munawir, S. (2014). Analisa Laporan Keuangan. Yogyakarta: Liberty. Mustafa. (2017).

Manajemen Keungan. Yogyakarta: CV Andi Offset.

Santoso, Singgih. (2014). Statistik Parametrik. Edisi Revisi. Jakarta: Prestasi Pustaka.

Sitanggang. (2013). Manajemen Keuangan Perusahaan Lanjutan. Edisi Pertama. Jakarta: Mitra Wacana Media.

Sugiyono. (2013). Metode Penelitian Kuantitatif, Kualitatif, dan R\&D. Bandung: Alfabeta.

Sartono, A.R. (2014). Manajemen Keuangan Teori Dan Aplikasi. Edisi Empat.Yogyakarta: BPFE.

Sugiyono. (2016). Metode Penelitian Pendidikan: Kuantitatif, Kualitatif, dan R\&D. Bandung: Alfabeta.

Taruna Jhoni Priabodo, Topowijoyo, dan Devi Farah Azizah. (2014). Pengaruh Struktur Aktiva, Tingkat Pertumbuhan Penjualan, dan Profitabilitas terhadap Struktur Modal, Studi pada Tekstil dan Garmen yang Listing di BEI Periode

2010 2012. Jurnal Administrasi Bisnis, Vol.9, No.1.

Watung, Abraham Kelli Sion., Ibonne S. Saerang dan Hizkia H.D. (2016). Pengaruh Rasio Likuiditas, Aktivitas, Profitabilitas, dan Struktur Aktiva terhadap Struktur Modal Industri Barang Konsumsi di Bursa Efek Indonesia. Jurnal EMBA, 4(2), h: 726-737. ISSN: $2303-1174$.

Wiagustini, L. (2014). Dasar-Dasar Manajemen Keuangan. Denpasar: Udayana University Press.

Widyaningrum, Yunita. (2015). Pengaruh Profitabilitas, Struktur Aktiva, dan Ukuran Perusahaan terhadap Struktur Modal pada Perusahaan Manufaktur yang Terdaftar di BEI 2010-2013. Skripsi Universitas Negeri Yogyakarta.

Yamin, Sofyan dan Kurniawan, Heri. (2014). SPSS Complete: Teknik Analisis Terlengkap dengan Software SPSS. Jakarta: Salemba Infotek. 